\title{
New States in World Politics: Prospects and Challenges
}

\author{
${ }^{1}$ Dr. Ejikeme Jombo Nwagwu, ${ }^{2}$ Ugwueze, Michael Ikechukwu \\ Department of Political Science, University of Nigeria, Nsukka \\ Department of Political Science, University of Nigeria, Nsukka
}

\begin{abstract}
The study was basically a qualitative one designed to underscore the prospects and challenges of new states in world politics. It theorized the new states in terms of age and development and came to the conclusion that new states in terms of development face stiffer challenges in the contemporary new world order especially as a result of low level of technological development and prevailing maladministration. The study revealed that globalization in world political order does not serve the interest of developing and underdeveloped countries. It is a modern colonization mechanism to perpetuate underdevelopment of these countries. The work therefore suggested that advanced countries that are technologically developed should assist the new states in reducing the world poverty rate which is a serious global security threat. It also recommended that the political leadership in the new states should work hard to ensure drastic reduction of bad governance and by extension corruption.
\end{abstract}

Keywords: New States, World Politics, Maladministration, Bad Governance, Prospects and Challenges.

\section{Introduction}

World politics, also called global or international politics, is a theatre of competing state forces where both the old and new states are engaged in the exploitation of world mineral resources in yet another conflicting milieu. This competitive process rekindles the anarchy of the international system and permeates master-slave relationship between and among states. The geopolitical entity called state (whether old or new) has continued to acquire considerable importance both in theory and practice especially as it remains an indispensable unit of analysis in the global political terrain. Many scholars have attempted a study of the state in terms of its indispensable role in the global system (Lenin, 1976; Nnoli, 2003; Onuoha, 1992 and 2008; Mingst, 1999). Similarly, the end of the Second World War brought into existence a number of new states in Asia and Africa. These states came into being as a result of the politics of decolonization on the part of the imperialist powers and urge for nationalism on the part of the colonized countries (Prachi, 2013). The First World War which was fought to save the world for democracy had added to the urge for political independence and autonomy in the subjugated and colonized countries, and by the end of the outbreak of the Second World War, political scene in the whole of Africa was agitating to throw away the yoke of colonialism with the belief that the moment colonialism is defeated, imperialism would die a natural death. However, following the emergence of new states in the world politics with the attendant globalization, the master-slave relationship of the post-colonial imperialism has been reinforced.

Consequently, extant literature abounds on both the meaning and theories of the state but no such thing as the theory of the new states. Perhaps, the Marxian scholars have made a lot of efforts in studying the new states (Slater, 2004; Brewer, 1990; Kiernan, 1995; Ake, 1981; Frank, 1969; Mommsen, 1980). In fact, the studies on dependent, center-peripheral and post-colonial states are assumed to be studies on new states. However, in the post-colonial state studies, the ideas of conceptualization and theoretical understanding of new states as well as the contemporary challenges faced by them in the New World Order are yet to be studied well enough. In view of the foregoing, the study is designed to fill the afore-stated gap especially given the revolution in information and communication technology (ICT). It utilized qualitative methodologies in generating and analyzing data due largely to the availability of information in the secondary source.

The work is divided into six segments of introduction, theoretical/conceptual explanation of the new states, making of the new states in the international system, challenges of new states in world politics: the African experience, reducing the inequality of states in the international system and conclusion respectively.

\section{Theoretical/Conceptual Explanation of New States in World Politics}

The career of the state in international relations research has been a peculiar one, central as a matter of faith, but often taken for granted the theoretical sideshow (Kahler, 2000). While not disagreeing with the foregoing Kahler's observation, some scholars have made attempts both in definition and theory aimed at understanding the state (Onuoha, 1992; Mingst, 1999; Jackson and Rosberg, 1985). However, while extant literature abounds on the concept of state and its theoretical underpinnings, not much attention of such has been 
extended to explaining the new states, either because they are part and parcel of the state system or that scholars' attention is yet to be drawn considerably to the plights of the new states in the new world order, especially given the stratification that characterizes the international system much to their disadvantage. Interestingly, Marxian scholars (as earlier noted) have attempted to explain the problems of new states from the stand-point of dependency and imperialism (Offiong, 1980; Mommsen, 1980; Kiernan, 1995, Slater, 2004). While these scholars have tried in offering the theoretical basis of dependency that characterizes the less developed countries that largely constitute the new states, there was no direct approach to the explanation of the new states in global system either in terms of age or levels of development. Therefore, the concept of new states would be explained through the two contending theoretical underpinnings. These include:

- Theorizing the new states in terms of age, and

- Theorizing the new states in terms of development.

\section{Theorizing New States in Terms of Age}

The Peace Treaty of Westphalia (1648) has given some characteristic meanings to the understanding of the modern state system. This treaty which ended the 30 years war (1618-1648) between the Holy Roman Empire and the rest of Europe led to the cartographical division of the world based on defined boundaries. For a state to be so called, the following features must be present:

- A clearly defined territory or boundary

- Government within the territory

- Population and

- Sovereignty

Ever since then, the primary understanding of state is that it is a political institution of sufficient organized authority and power to govern a defined territory and its population and to remain independent of other states (Jackson and Rosberg, 1985, cited in Onuoha, 1992). With the state understood in this viewpoint, new states are those ones that recently acquired independent political control over their own affairs (Scott, n.d). These include the majority of the countries in Asia and Africa as well as Latin America, Europe and Oceania which, before 1945, were under some form of colonial rule. This definition to a large extent satisfies the idea of new states in terms of age. The yardstick used in measuring new states here is strictly age, the level of development notwithstanding. In terms of age, below is the list of new states in the world politics formed after 1945.

Table 1: The List of New States in Terms of Age (those formed after 1945) Africa

\begin{tabular}{|c|c|c|c|}
\hline S/No & State & Date of formation & Colonizer \\
\hline 1 & Algeria & 1963 & France \\
\hline 2 & Angola & 1975 & Portugal \\
\hline 3 & Benin & 1960 & France \\
\hline 4 & Botswana & 1966 & Britain \\
\hline 5 & Burkina Faso & 1960 & France \\
\hline 6 & Burundi & 1962 & Belgium \\
\hline 7 & Cameroun & 1960 & France \\
\hline 8 & Cape Verde & 1975 & Portugal \\
\hline 9 & Central African Republic & 1960 & France \\
\hline 10 & Chad & 1960 & France \\
\hline 11 & Comoros & 1975 & France \\
\hline 12 & Democratic Republic of Congo & 1960 & Belgium \\
\hline 13 & Congo Republic & 1960 & France \\
\hline 14 & Cote d'Ivoire & 1960 & France \\
\hline 15 & Djibouti & 1977 & France \\
\hline 16 & Equatorial Guinea & 1968 & Spain \\
\hline 17 & Eritrea & 1993 & Ethiopia \\
\hline 18 & Gabon & 1960 & France \\
\hline 19 & Gambia & 1965 & Britain \\
\hline 20 & Ghana & 1957 & Britain \\
\hline 21 & Guinea & 1958 & France \\
\hline 22 & Guinea Bissau & 1974 & Portugal \\
\hline 23 & Kenya & 1963 & Britain \\
\hline 24 & Lesotho & 1966 & Britain \\
\hline 25 & Libya & 1947 & Italy and France \\
\hline 26 & Madagascar & 1960 & France \\
\hline 27 & Malawi & 1964 & Britain \\
\hline 28 & Mali & 1960 & France \\
\hline 29 & Mauritania & 1960 & France \\
\hline 30 & Mauritius & 1968 & Britain \\
\hline
\end{tabular}


New States in World Politics: Prospects and Challenges

\begin{tabular}{|l|l|l|l|}
\hline 31 & Morocco & 1956 & Spain \\
\hline 32 & Mozambique & 1975 & Portugal \\
\hline 33 & Namibia & 1990 & Broke out of South Africa \\
\hline 34 & Niger & 1958 & France \\
\hline 35 & Nigeria & 1960 & Britain \\
\hline 36 & Rwanda & 1962 & Belgium \\
\hline 37 & Sao Tome and Principe & 1975 & Portugal \\
\hline 38 & Senegal & 1960 & France \\
\hline 39 & Seychelles & 1976 & Britain \\
\hline 40 & Sierra Leone & 1961 & Britain \\
\hline 41 & Somalia & 1960 & Trust territory \\
\hline 42 & South Africa & 1961 & Britain \\
\hline 43 & South Sudan & 2011 & Broke out of Sudan \\
\hline 44 & Sudan & 1956 & Egypt and later Britain \\
\hline 45 & Swaziland & 1968 & Britain \\
\hline 46 & Tanzania & 1961 & Britain \\
\hline 47 & Togo & 1960 & France \\
\hline 48 & Tunisia & 1962 & France \\
\hline 49 & Uganda & 1962 & Britain \\
\hline 50 & Zambia & 1964 & Britain \\
\hline 51 & Zimbabwe (formerly South Rhodesia) & 1980 & Britain \\
\hline
\end{tabular}

Source: http://en.wikipedia.org/wiki/List_of_sovereign_states_by_date_of_formation, retrieved 30/10/2013

Table 2: The List of New States in Terms of Age (those formed after 1945) America

\begin{tabular}{|l|l|l|l|}
\hline S/No & State & Date of formation & Colonizer \\
\hline 1 & Antigua and Barbuda & 1981 & Britain \\
\hline 2 & Bahamas & 1973 & Britain \\
\hline 3 & Barbados & 1966 & Britain \\
\hline 4 & Belize & 1964 & Self governing \\
\hline 5 & Dominica & 1978 & Britain \\
\hline 6 & Grenada & 1974 & Britain \\
\hline 7 & Guyana & 1966 & Britain \\
\hline 8 & Jamaica & 1962 & Britain \\
\hline 9 & Saint Kitts and Nevis & 1983 & Britain \\
\hline 10 & Saint Lucia & 1979 & Britain \\
\hline 11 & Saint Vincent and the Grenadines & 1979 & Britain \\
\hline 12 & Suriname & 1975 & Netherland \\
\hline
\end{tabular}

Source: http://en.wikipedia.org/wiki/List_of_sovereign_states_by_date_of_formation, retrieved 30/10/2013

Table 3: The List of New States in Terms of Age (those formed after 1945) Asia

\begin{tabular}{|c|c|c|c|}
\hline $\mathrm{S} / \mathrm{No}$ & State & Date of formation & Colonizer \\
\hline 1 & Bahrain & 1971 & Iran \\
\hline 2 & Bangladesh & 1971 & Pakistan \\
\hline 3 & Brunei & 1984 & Britain \\
\hline 4 & Cambodia & 1989 & Freed from Vietnam \\
\hline 5 & China & 1949 & Britain \\
\hline 6 & India & 1947 & Netherlands \\
\hline 7 & Indonesia & 1949 & Britain \\
\hline 8 & Israel & 1948 & British mandate \\
\hline 9 & Jordan & 1946 & British mandate \\
\hline 10 & Kuwait & 1991 & Iraq \\
\hline 11 & Kyrgyzstan & 1991 & Soviet Union \\
\hline 12 & Laos & 1953 & France \\
\hline 13 & Malaysia & 1957 & Britain \\
\hline 14 & Maldives & 1965 & Britain \\
\hline 15 & Myanmar (Burma) & 1948 & Britain \\
\hline 16 & North Korea & 1948 & - \\
\hline 17 & Oman & 1950 & Portugal \\
\hline 18 & Pakistan & 1947 & British India \\
\hline 19 & Qatar & 1971 & Britain \\
\hline 20 & Singapore & 1965 & Britain \\
\hline 21 & Sri Lanka & 1972 & Britain \\
\hline 22 & Syria & 1961 & UAE \\
\hline 23 & Tajikistan & 1991 & Soviet Union \\
\hline 24 & Timor-Leste & 2002 & Indonesia \\
\hline 25 & Turkmenistan & 1991 & Soviet Union \\
\hline 26 & Uzbekistan & 1991 & Soviet Union \\
\hline 27 & Vietnam & 1945 & Japan and France \\
\hline 28 & Yemen & 1990 & - \\
\hline
\end{tabular}


Source: http://en.wikipedia.org/wiki/List_of_sovereign_states_by_date_of_formation, retrieved 30/10/2013

Table 4: The List of New States in Terms of Age (those formed after 1945) Europe

\begin{tabular}{|l|l|l|l|}
\hline S/No & State & Date of formation & Colonizer \\
\hline 1 & Belarus & 1991 & Soviet Union \\
\hline 2 & Bosnia and Herzegovina & 1992 & Yugoslavia \\
\hline 3 & Cyprus & 1960 & Britain \\
\hline 4 & Czech Republic & 1993 & Formerly Czechoslovakia \\
\hline 5 & Estonia & 1991 & Soviet Union \\
\hline 6 & Latvia & 1990 & Soviet Union \\
\hline 7 & Lithuania & 1990 & Soviet Union \\
\hline 8 & Macedonia & 1991 & Yugoslavia \\
\hline 9 & Malta & 1964 & Britain \\
\hline 10 & Moldova & 1991 & Soviet Union \\
\hline 11 & Slovakia & 1993 & Formerly Czechoslovakia \\
\hline 12 & Slovenia & 1991 & Soviet Union \\
\hline 13 & Ukraine & 1991 & Soviet Union \\
\hline
\end{tabular}

Source: http://en.wikipedia.org/wiki/List_of sovereign_states by date of formation, retrieved 30/10/2013

Table 5: The List of New States in Terms of Age (those formed after 1945) Oceania

\begin{tabular}{|l|l|l|l|}
\hline S/No & State & Date of formation & Colonizer \\
\hline 1 & Fiji & 1970 & Britain \\
\hline 2 & Kiribati & 1979 & Britain \\
\hline 3 & Marshall Islands & 1986 & USA \\
\hline 4 & Micronesia & 1986 & USA \\
\hline 5 & Nauru & 1968 & UN Trusteeship \\
\hline 6 & Palau & 1994 & UN Trusteeship \\
\hline 7 & Papua New Guinea & 1975 & Australia \\
\hline 8 & Samoa & 1962 & New Zealand \\
\hline 9 & Solomon Islands & 1978 & Britain \\
\hline 10 & Tonga & 1970 & Britain \\
\hline 11 & Tuvalu & 1978 & Britain \\
\hline 12 & Vanuatu & 1980 & France and Britain \\
\hline 13 & Armenia & 1991 & Soviet Union \\
\hline 14 & Azerbaijan & 1991 & Soviet Union \\
\hline 15 & Georgia & 1991 & Soviet Union \\
\hline 16 & Kazakhstan & 1991 & Soviet Union \\
\hline
\end{tabular}

Source: http://en.wikipedia.org/wiki/List_of_sovereign_states_by_date_of_formation, retrieved 30/10/2013

A state, in the sense of modern state system, cannot be so called without sovereignty, and sovereignty cannot be exercised while an entity is under some forms of colonial rule. This is why the understanding of the formation of new states assumed the period of independence rather than the actual date of formation. To this end, Nigeria became a modern state in 1960 instead of 1914 when the Northern and the Southern protectorates were amalgamated to form an entity called Nigeria.

From the above table 3 under Asia, it is observable that China and Israel are all new states; hence, the expectation that they suffer the same fate - master-slave relationship - of the new states in the international system. However, such is not the case since both Israel and China are indispensable world powers notwithstanding that the modern states of Israel and China just emerged in 1948 and 1949 respectively. On the other hand, any state not mentioned in the above tables, including Liberia, Haiti, Ethiopia, Chile, among others are old states in terms of age. Meanwhile, their age is yet to translate to any significant global assertion of historical relevance in terms of power and influence in the international system. To this end, understanding the new states strictly in terms of age could be misleading. The reason being that there is a sharp disconnect between the new and the old states in global politics depending on their access to global resources. Old states are traditionally known to have greater access to global resources than the new states (notwithstanding the location of such resources) and this is not necessarily as a result of their age, but due to their overall social development.

\section{Theorizing New States in Terms of Development}

The world politics is a capitalist dominated system historically designed to subjugate the less developed countries and perpetually beat them to submission through dependency and imperialism (Offiong, 1980; Mingst, 1999; Mommsen, 1980). According to Mingst (1999: 97), "the structure of the international system reflects stratification as well as polarity". Stratification in this case refers to the uneven access to resources by different groups of states and it is a key to understanding the radical Marxist notion of the international system where new states mostly play the role of the second-fiddle. The determining factors in this 
stratification include military strength, economic power, stable political leadership, mineral deposit, among others. While these indicators are found in large quantity and quality in many old states, they are found wanting (except the mineral deposits) in many new states of the world.

New states in terms of development include all those states that are economically backward, where unemployment, poverty, hunger, political instability, violence and many other social vices thrive. Having understood state in this axiom, China and Israel cannot be categorized as new states. On the other hand, Liberia, Haiti, Chile and many others are all new states, age notwithstanding.

Figure 1: understanding the new states from a stratified pyramid of the world politics

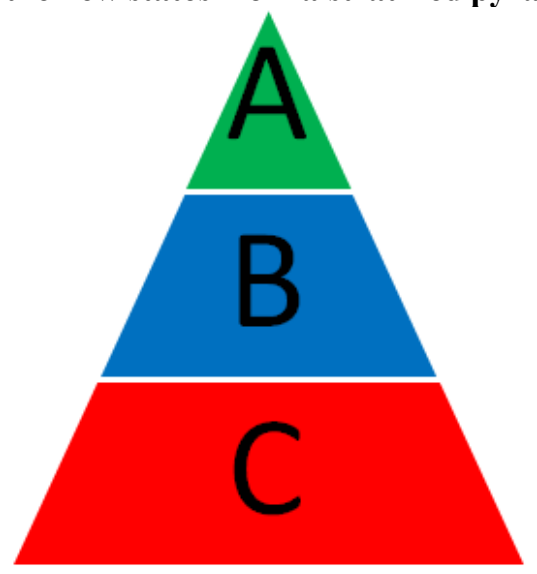

All the states that fall within the apex of the pyramid labeled "A", are developed economically, politically, socially, militarily, and otherwise and are therefore categorized as old states. Age here is measured in terms of achievement and development. Most of the states in the North America and Europe fall within the peak of the pyramid, including Japan, China and Israel in Asia. In the "B" division of the pyramid are developing states. They can also be called new states in transition. These states have developing economies where poverty is seriously being fought, unemployment tamed and hunger in serious check. In the world politics, otherwise the global system, they suffer almost the same fate with the less developed countries but with serious moderation. The Latin American states like Brazil, Argentina, Mexico and such Asian states like South Korea, India, Qatar as well as Malaysia fall within this categorization.

Those who largely occupy the base of the pyramid are labeled less developed countries where all the new states in terms of age (except China and Israel) and the old ones like Liberia, Ethiopia, Haiti, etcetera who are underdeveloped fit into. These states joined together have the highest world population, land mass, mineral deposits, and record the highest rates of poverty, unemployment, hunger, instability, among others. As a matter of specificity, virtually all the African states, Middle-East (except Israel) as well as many more in Latin America, Asia and Europe (Greece, for example) occupy the "C" position in the pyramid. Ironically, these states, mostly those in Africa and Asia (Middle-East precisely) have the highest mineral deposits like crude oil, gold, uranium, among others as well as possess the best climatic conditions, record the least natural disasters, and yet are the worst-hit by hunger, poverty, unemployment and death issuing from starvation and man-made disasters. It is on this basis that such derogatory terms like third world countries, underdeveloped states, and peripheral states, among others coined. All the new states of the world in terms of development are inescapably tied to the rung of the pyramid.

From the foregoing theoretical explications, new states are not only those that are new in terms of age subject to when they secured political independence and self rule, but also those whose developmental strides are still at the rudimentary level. In fact, the understanding of new states in the international system is synonymous with their level of development because that is what determines the capacity of states to assert themselves in the global politics. States that are developed also have and wield more powers and are likely to benefit more in the global resources whose territorial location and control have been affected by globalization to the disadvantage of less developed ones. In fact, globalization has worsened the continued understanding of the state from the stand-point of sovereignty and if sovereignty remains a cardinal tool for measuring the state, then there are very few states in the international system.

Accordingly, one can therefore argue that old states are those ones that can exert greater influence in the international system and whose borders are not as porous as what obtains in many developing states even with the emergence of globalization and information technology; while new states are those states that lack the requisite technology to challenge the old states at the era of globalization.

From the foregoing analysis, we can make the following deductions: 
- All new states are post-colonial states

- All new states are either developing or underdeveloped

- All new states are mostly found within the continents of Africa, Asia and Latin America

- All new states are at the receiving end of globalization.

\section{Making of New States in the International System}

There is no straight-jacketed theoretical means of making a new state in the international system. Whereas some states are products of wars, others were created through negotiations and bargaining. Indeed, the modern state system rooted on the threshold of the Westphalia treaty is a product of political alchemy arising from wars. No war has ever ended with war. The end or resolution of wars is always reached through dialogues and peace appeals. The establishment of the modern state system in 1648 through the Westphalia treaty ended a thirty-year war (1618-1648) between and among the European Empires, thereby suggesting that the very essence of state creation is to resolve disputes. The making of new states, therefore, can assume the forms of war or peace and/or the combination of both.

Consequently, the following stages can give credence to state creation in the international system outside the process of securing independence from colonial powers:

- Looting

- Truce

- Occupation

- Disintegration

- Recognition

Looting: Oppenheimer (1970) noted that looting comprises of robbery and killing in border fights, endless combats broken neither by peace nor by armistice. It is marked by killing of men, carrying away of children and women, looting of important resources either of animals or other valuables, destruction of property and burning of houses both private and public and even if the offenders or rebels are defeated, they return in stronger and more determined force, impelled by blood feud. If the rebel forces were able to assert themselves beyond the strength of the mainstream forces, then they are likely to be established as a state should that be their request. This style was adopted in Sudan and it led to the creation of South Sudan. It was also tried in the case of Biafra but it could not receive recognition by the international law in addition to the inability of the Biafran rebel forces to defeat the Nigerian military, hence its failure. Similarly, the case of Ethiopia and Eritrea in fierce civil war for over thirty years, and Eritrea subsequently emerged a sovereign state. In fact, the history of many old and new states is replete with well-known instances of mass expeditions of this averred looting style and the result has been the creation of new states.

Truce: This stage entails the brokering of peace process as a result that conquest from the mainstream power has become difficult, hence, the need for peace and stoppage of the blood feud. This was also obtainable in the case of South Sudan and Eritrea. Many decades of the war between the rebel forces and the Sudanese military could not produce a victor and the international community was becoming fed up with the number of lives being wasted daily and was therefore faced with no other option than to try and broker peace with the Sudanese and the rebel governments. The result was the creation of South Sudan in 2011.

Occupation: Occupation has added decisive factor in the creation of new states. The state of Israel is a good example of a state created through occupation. Though the establishment of the Israeli state took many decades of negotiations and bargaining within the United Nations, it eventually settled for its present territory in the Middle-East within the Palestinian boundary out of many options given, including in Africa.

Disintegration: State creation through disintegration can occur as a result of wrong political calculation and economic policies such as the glasnost and perestroika of Mikhail Gorberchev of the defunct Soviet Union which led to the disintegration of that country into fifteen sovereign states with Russia retaining the veto power of the former USSR in the United Nations Security Council. Similar policies are capable of producing similar results elsewhere given similar characteristics of the defunct Soviet Union.

Beyond wrong political calculation and economic policies, looting, either in the forms of killing, stealing and kidnapping in the border territories or corruption and embezzlement of public funds by the politicians, can also lead to disintegration of a country. Meanwhile, it is possible to find in a state the attributes of looting, truce, disintegration or even occupation as contributory factors to its creation.

Recognition: While the first four can be regarded as sociological approach to state creation, recognition is a legal approach. It takes social conditions of looting, truce, occupation or disintegration and the legal imputation of recognition to make a state in the international system. Recognition is an exclusive preserve of the international law and most fundamental in state creation without which an entity remains a persona non grata in international politics while measuring the state as a unit of analysis. Given certain conditions, such an entity can be welcomed as an international non-governmental organization but not as a state. Besides recognition by the 
international law, the Montevideo Convention on the Rights and Duties of States (1933) laid down the following criteria as the condition for state creation. These criteria include:

- The state (to be created) must possess a permanent population

- It must have a defined boundary

- There must be government and

- The state must possess the capacity to conduct international relations.

These criteria are just reinforcement of the features of a state in Westphalia order, and so might not help much in understanding state creation, hence, the five prevailing social conditions.

Therefore, while the sociological approach provides the necessary conditions for state creation, the legal approach, based on recognition by the international law, offers the sufficient condition. Of course, it is noteworthy that without sufficient conditions, it cannot produce a desirable outcome for political change and vice versa. Perhaps, while many states that were under colonial rules fought and secured their independence and statehood, others got theirs through nonviolent negotiations and bargaining. Almost all the states in Africa that were colonized got their independence and by extension statehood through the latter processes of nonviolent negotiations and bargaining.

\section{Challenges of New States in World Politics: The African Experience}

In the modern world of states, the position of a country is largely determined by its power, which can be understood either in terms of economic resources or military capabilities, or both. Although some African countries like Nigeria, South Africa, Egypt, among others, meet this criterion in their respective sub-regions, on a global scale, they (like many other new states) have been increasingly marginalized especially with the massive development in the world of science and technology. This development carries with it other political and economic implications of proportional concern to political scientists while discussing the challenges of new states in the world politics. Against this backdrop, the new states especially those of Africa, Asia and Latin America have suffered untrammeled political cum economic exploitations clothed in many foreign diplomatic relations that are in most cases hostile to both the people and the environment. At a time, it was called slavery, at other times, colonialism and neo-colonialism but the most permeating contemporary avatar that is eroding the sovereignty of many new states in the international system is globalization. Due largely to the rudimentary development of science and technology in the new states, they are unable to bargain favourably in the international division of labour and the social wealth it produces.

Based on the foregoing, the challenges of new states especially those of Africa, Asia and Latin America in world politics are bifurcated in nature. On one hand is the internal problem of bad governance which breeds corruption, and on the other hand, the external problem of globalization which suffocates genuine internal development efforts by the new underdeveloped or developing states.

\section{Internal Problem of Bad Governance}

This remains the greatest challenge confronting the new states upon which other factors including the external problem of globalization are built. Indeed, bad governance has been identified as one of the most critical factors responsible for stunted growth and development, insecurity, unemployment, and poverty (Fallah, 2006; Obama, 2013; Ezekwesili, 2013; Kiani, 2013). While fielding answers to journalists on some nagging questions of global concern, the President of the United States of America, Barrack Obama, noted that the upsurge of terrorist groups could be situated on the fact that countries are not delivering for their people and unless strong and responsive democratic institutions are built, insecurity would continue (Obama, 2013). Similarly, a former World Bank Vice President for Africa and one time Nigerian Minister of Education, Dr Oby Ezekwesili, speaking specifically about Nigeria, has attributed the challenges facing the country to poor governance and the monotonous economic structure (Ezekwesili, 2013). In his view, Dr El Bakri, African Development Bank Vice President for Operations (cited in Fallah, 2006), argued that poor governance in Africa has not only had costly consequence for the productive use of resources but also constrained the ability of African countries in mobilizing resources.

As a corollary to the above observations, bad or poor governance which is akin to maladministration breeds corruption, poverty, insecurity and other social vices that are very inimical to societal development. By extension therefore, it erodes economic development and creates favourable atmosphere for external domination through globalization.

\section{External Problem of Globalization}

Political scientists have developed successful research agenda on the political effects of globalization (Kahler, 2000; Onuoha, 2004; Asobie, 2002; Olayode, 2006). Olayode (2006:10) noted that: 
globalization has become an important theme of the post Cold War discussion of the nature of the international order. Although rarely tied to any clearly articulated theory. It (globalization) has become a very powerful metaphor in the sense that a number of universal processes are at work generating increased interconnection and interdependence between states and between societies. The result is that territorial boundaries are becoming decreasingly important, that traditional understanding of sovereignty is being undermined and that individual regions must be viewed within a broader global context.

Essentially, globalization is seen by liberal scholars as a process of freeing economies so that trade between countries can take place more easily (Onuoha, 2004). Freeing in this context entails providing unrestrained opportunities for businesses to thrive between and among states while reducing the role of the state in the market. Accordingly, Olisa (1999) cited in Onuoha (2004) argued that globalization is an on-going gigantic movement initiated and pushed forward by the developed capitalist and industrial western nations.

On the other hand, the Marxist scholars see globalization as the universalization of capitalism in its speculative variety (Asobie, 2002 cited in Onuoha, 2004). Asobie further argued that globalization is a technique of ideological marketing devised by global entrepreneurs primarily to counter a rising trend in the underdeveloped world. The idea of globalization is a grand design to villagize the world so much so that one can access the whole world from the comfort of one's room. Indeed, it aims at weakening (if not removing) traditional and jurisdictional boundaries and barriers of individual state much to the disadvantage of the new ones. However, while trade liberalization is the motor that drives globalization, information and communication technology (ICT) is the oil that fuels it.

Consequently, the new states especially those that are highly underdeveloped or developing are the worst affected in this globalization project; the reason being that they are largely technologically backward and are therefore predisposed to consumption than production. In view of this and along with the monopolization of the international economy by those who produce (in this case, the industrialized countries), the dictate of the trade movement is at the advantage of the producing countries and the efforts made by some underdeveloped or developing new states are often sabotaged by the old established states. Globalization is one of such grand strategies of sabotage used by the industrialized old states against the less industrialized new states. In fact, all the nemeses of the ancient slavery, naked colonialism, coded neocolonialism and imperialism have been summarized in globalization. The implication of the foregoing is that, the world politics is still characterized by inequalities and exploitations of the highest order executed with unmitigated impunity where might is right.

Notwithstanding the foregoing observations, specifically at independence in 1960, Nigerians were in high spirit that come what may, very soon the country would join the world league of developed countries. To make real this dream, the Nigerian government immediately began to make assertive foreign policies designed to actualizing this dream and it was not long before it earned the name "Giant of Africa". This was due largely to the roles it played in ensuring that many African states secured their independence from colonial rule, including fighting apartheid regime in South Africa and spearheading the liberation struggle in Angola which earned it the membership of the Frontline States. Meanwhile, in terms of human and material resources, Nigeria is endowed to the tune of becoming the world power given the requisite commitment it deserves. This endowment has helped it in the promotion of OAU (now AU), membership of the Frontline States, and peacekeeping operations around the globe, among other leadership roles both within and outside Africa (Ibeanu, 2010; Oculi, 2010; Sanda, 2010; Okolie, 2010).

However, contrary to this expectation, Nigeria after 53 years of independence (even with enormous resources at its disposal) is still ravaged by poverty, hunger, unemployment, political instability and terrorism and the dream of becoming a developed country is still in inchoateness, if at all conceived. In fact, the country is even battling to regain its former glory let alone improving on what hitherto existed. The question remains, why is the situation so? The situation is so because Nigeria has ceased from producing anything. The country largely depends on importation and any nation that thrives on importation is bound to be a pariah state. Countries that suffer such fate will definitely lose the grip of any power project in the international system. At present, the only surviving instinct by Nigeria as a power to reckon with in Africa (not even the international system) is its intimidating size which is inadequately exploited, and the moment it is broken, whatever that remains of the entity would be confined to the dustbin of history.

Perhaps, from the look of things, if there is no significant effort made by the Nigerian government in urgently addressing unemployment through industrialization, sooner or later, the country would be unable to manage the mass of unemployed youths and the result would be very catastrophic and capable of breaking the country into many sovereign states reminiscent of a banana republic.

\section{Reducing the Inequality of States in the International System}

It is our firm belief that inequality is part and parcel of the world's capitalist history and its abolition in the foreseeable future is not only bleak but also utopian. However, the gap between the rich and the poor nations can be moderated. Therefore, we can at best advocate for its reduction which is feasible in the present world 
order. This is because inequality is not just bad for social justice, it is also bad for economic efficiency (Oxfam, 2000 cited in Shah, 2011).

Many factors have contributed to the present inequality that envelopes the international system much to the disadvantage of the new and underdeveloped or developing states. Some of these factors include: slavery, colonialism and neocolonialism. Perchance, it is not in our best interest to re-visit these social injustices meted out to the Third World countries especially because they have been over-flogged in the literature. Our interest is in the modernization of these injustices cloned in a more amenable term - globalization - with an unchanged philosophy where might is right. While slavery in its brute force (as it was the case before the $20^{\text {th }}$ Century) and colonialism in its naked phase (as it was the case before the end of the Second World War) have been condemned by all, including the perpetrators, not much of such condemnation has been extended to globalization especially by the perpetrators who were still part of the old system that produced slavery and colonialism. This social avatar has given rise to brain-drain especially in Africa - the cradle of civilization. Meanwhile, there is no significant difference between globalization of the new era and slavery and colonialism of the old era except that there appears to be no naked and brute application of force in the new system. The underlining practice has remained the extrication of human resources and exploitation of the new states by those who determine "who gets what, when and how" in the international system. In addition to the foregoing, leaders of the Third World countries (the new states) are not helping matters in ensuring that the problem of bad governance is curtailed; thereby exacerbating the problems already faced by the new states in the international system.

\section{Recommendation}

On the basis of the above, the following recommendations are necessary:

- Leaders of the new states especially those in Africa, Asia and Latin America should not think that the industrialized countries would be quick to transferring the requisite technology that would give way for efficient global competition. Technology, like knowledge, is not given, it is taken or even stolen. China is a good laboratory on how technology can be stolen for the good of the people and therefore should serve as a model for the rest of the new states. India, Brazil and South Korea have keyed into this and should be emulated by the rest. However, because of a longtime maladministration characteristic of many new states, imitation of this radical model adopted by the Asian Tigers becomes difficult. For this reason, leaders of the new states should ensure that bad governance is seriously put on check to enable development gain entrance.

- Scholars are well aware of the hypocritical role played by the industrialized countries designed to beat the new states to submission perpetually. In line with this observation, studies should be expedited by scholars in order to bring to notice of the leaders of new states the prognostic implications of following straightjacketed development model.

- Deriving from the fact that the international system is anarchical with conflicting national interests, survival therefore becomes of the fittest. The new states should understand that the solutions to their development woes lie within their environments. Both leaders and scholars should therefore stop blaming the advanced countries for the problems that arose from the centuries and millennia of slavery and colonialism, but instead strategize on how to fight the permeation of these social vices with the emergence of globalization through industrialization and ICT-based research. We cannot continue to dwell in the past, while losing the grips of the present; thereby deepening the already bleak future.

- Finally and very importantly, the industrialized nations that offer the direction of world politics should understand that the more poor countries there are in the international system, the more crises there would be in the world and not even the developed countries would be spared given a contrapuntal eruption of such crisis issuing from hunger and poverty. Interestingly, the only rich man in the midst of poor men is not safe even in his riches. We therefore suggest that even if they cannot assist the new states directly, they should not sabotage their efforts and instead allow them to concentrate on their development projects. The situation whereby World Bank and International Monetary Fund (IMF) are being used to sabotaging and dictating the economic policies of the new states is not only unacceptable but also condemnable. Consequently, no logic can explain why the United Nations Security Council has remained the way it is with five states wielding the veto power even with the proliferation of new states in the international system and the increasing complexity of the world governing body. If this international organization - the United Nations was indeed established to maintain international peace and security as well as prevent further world wars, then the reformation of the Security Council becomes imperative. Else, the world should expect more wars given the proliferation of new states without corresponding attention given to the plights of their citizens. 


\section{Conclusion}

The study of new states in world politics is invariably a study of post-colonial states on the world stage. They both suffer the same fate in the international system due largely to the rudimentary stage in the development of technology and their dependence on the industrialized countries for survival. There was an attempt to explain the concept of new states in the international system executed through two contending theoretical viewpoints. On the one hand is the view that new states, in terms of age, are those that recently and most precisely secured their independence or self rule after the Second World War from 1945. On the other hand is the conceptualization that new states, in terms of development, are those that are technologically backward with accompanying underdevelopment made manifest through the levels of poverty, unemployment, hunger and many other social vices. To this end, virtually all African states are new states notwithstanding the ages of Ethiopia and Liberia as well as Egypt - the foremost self-governing African states.

The research observed that the most outstanding challenge facing the new states in the world politics is bad governance which breeds corruption and other accompanying social problems as well as globalization which has gradually eroded the sovereignty of many new states and yet disallowing them a corresponding access to the industrialized countries where it (globalization) was conceived and nurtured. This has widened the gap between the old states (industrialized states) and the new states (less developed states), and has reinforced the slave role that the latter have continued to play over the past centuries and millennia. With Information and Communication Technology (ICT) and the accompanying trade liberalization, the sovereignty of the new states has been compromised much to their disadvantage.

In a nutshell, the study argued that while it would not be easy for the new states to extricate themselves from playing the slave role in the world politics, it is possible for them to assert themselves through coordinated and administrative commitment by the leaders capable of alienating the new states from dependent mentality. China and Israel took this bold step and today, they are indispensable world powers. Brazil, India, Mexico, Argentina, etcetera, are chanting this course and the result is becoming glaring. A society bereft of technological base is bereft of industrialization and derivatively bereft of development. Such society will continue to play the role of the second-fiddle in the international system until it is able to assert itself through coordinated development strategies. Not until the underdeveloped and developing states (new states) embrace good governance which enhances industrialization, development would remain a mirage and the hope of becoming one of the leading 20 economies by 20/20 (in the case of Nigeria) is an illusion.

\section{References}

[1]. Ake, Claude (1981). Political Economy of Africa. Nigeria: Longman Nigeria Plc Brewer, Anthony (1990). Marxist Theories of Imperialism: A Critical Survey. London: Routledge

[2]. Ezekwesili, Oby (2013). Bad Governance Behind Poverty in Nigeria. http://www.punchng.com/news/bad-governance-behindpoverty-in-nigeria-ezekwesili/. Retrieved $14^{\text {th }}$ June, 2014

[3]. Fallah, Bob (2006).bad Governance Is Africa's Major Problem. http://www.theperspective.org/forum/05/6200603.html. retrieved 14th June, 2014

[4]. Frank, Andre Gunder (1969). Capitalism and Underdevelopment in Latin America. New York: Modern Reader Paerbacks

[5]. Kahler, Milner (2000). The State of the State in World Politics. http://irps-academics.ucsd.edu/ irps/academics/Filesmkahler/SoState.pdf, retrieved $3^{\text {rd }}$ October, 2013

[6]. Kiani, Khaleeq (2013). Price of Bad Governance. http://www.dawn.com/news/1039894. Retrieved, 14 th June, 2014.

[7]. Ibeanu, Okechukwu (2010). "Nigeria's Role in the Promotion of the OAU/AU and Membership of the Frontline States". In A.M. Jega and J.W. Farris (eds.) Nigeria at Fifty: Contributions to Peace, Democracy and Development. Abuja: The Shehu Musa Yar'Adua Foundation. 17-36.

[8]. Joseph, William, Kesselman, Mark and Krieger, Joel (1996). Third World Politics at the Crossroads. Lexington: D.C. Heath and Company.

[9]. Kiernan, Victor G. (1995). Imperialism and its Contradictions. Great Britain: Routledge, Inc.

[10]. Lenin, Vladimir I. (1976). The State and Revolution. Peking: Foreign Languages Press

[11]. Mingst, Karen (1999). Essentials of International Relations. New York: W.W. Norton and Company.

[12]. Mommsen, Wolfgang J. (1980). Theories of Imperialism. New York: Random House.

[13]. Nnoli, Okwudiba (2003). Introduction to Politics. Enugu: Snaap Press Ltd.

[14]. Obama, Barrack (2013). Bad Governance Responsible for Boko Haram. http://www.nigeriavillagesquare.com/newsflash/badgovernance-responsible-for-boko-haram-obama.html. Retrieved 14th June, 2014.

[15]. Oculi, Okello (2010). "Nigeria's Role in the United Nations, the Commonwealth, and the Non-

[16]. Aligned Movement”. In A.M. Jega and J.W. Farris (eds.) Nigeria at Fifty: Contributions to Peace, Democracy and Development. Abuja: The Shehu Musa Yar'Adua Foundation. 37-51.

[17]. Offiong, Daniel (1980). Imperialism and Dependency: Obstacles to African Development. Enugu: Fourth Dimension Publishers.

[18]. Okolie, Andrews (2010). "Nigeria's Role in Peacekeeping in Africa: ECOMOG, Chad, Liberia, and Sierra Leone”. In A.M. Jega and J.W. Farris (eds.) Nigeria at Fifty: Contributions to Peace, Democracy and Development. Abuja: The Shehu Musa Yar'Adua Foundation. 99-124.

[19]. Olayode, Kehinde (2006). "Globalization, Sustainable Development and State Capacity in Africa", Nigerian Journal of International Affairs. 32 (1): 9-27.

[20]. Onuoha, Jonah (1992). What is the State? Enugu: Acena Publishers

[21]. Onuoha, Jonah (2004). "Globalization, the State and the Challenges of Unemployment in Nigeria". In J. Onuoha and P.U. Okpoko (eds.) Ethnic Nationalism and Democratic Consolidation: Perspectives from Nigeria and the United States of America. Nsukka: Great AP Express Publishers Ltd. 381-391. 
[22]. Onuoha, Jonah (2008). Beyond Diplomacy: Contemporary Issues in International Relations. Nsukka: Great AP Express Publishers Ltd.

[23]. Oppenheimer, Franz (1970). The Six Stages of the Creation of the State. http://www.lewrockwell.com/1970/01/franzoppenheimer/the-six-stages-of-the-creation-of-thestate/. Retrieved $30^{\text {th }}$ October, 2013.

[24]. Oppenheimer, Franz (1975). The State. New York: Free life.

[25]. Prachi, Mujumdar (2013). What has been the Impact of the Emergence of New States on the Nature of International Relations? http://www.preservearticles.com/2011068256/...html. Retrieved $3^{\text {rd }}$ October, 2013.

[26]. Sanda, Julie G. (2010). Nigeria's Global Role in Peacekeeping: From the Congo Through

[27]. Lebanon to Bosnia Herzegovina. In A.M. Jega and J.W. Farris (eds.) Nigeria at Fifty: Contributions to Peace, Democracy and Development. Abuja: The Shehu Musa Yar'Adua Foundation. 79-98.

[28]. Scott, Roger (n.d). "The Politics of New States". http://www.vanuatu.usp.ac.fj/courses/LA332_Jurisprudence/Articles/Scott.htm. Retrieved $3^{\text {rd }}$ October, 2013.

[29]. Shah, Anup (2011). "Poverty around the World". http://www.globalissues.org/article/4/poverty-around-the-world. Retrieved $1^{\text {st }}$ November, 2013.

[30]. Slater, David (2004). Geopolitics and the Post-Colonial: Rethinking North-South Relations. USA: Blackwell Publisher.

[31]. Umozurike, Oji U. (2005). Introduction to International Law. Ibadan: Spectrum Books Ltd. 